\title{
Sequence and regulation of psrA, a gene on the Sym plasmid of Rhizobium leguminosarum biover phaseoli which inhibits transcription of the psi genes
}

\author{
M. L. Mimmack, ${ }^{1}$ G. F. Hong ${ }^{2}$ and A. W. B. Johnston ${ }^{1}$ \\ Author for correspondence: A. W. B. Johnston. Tel: +44603 592777. Fax: +44603592250.
}

1 School of Biological Sciences, University of East Anglia, Norwich NR4 7TJ, UK

2 Institute of Biochemistry, Academica Sinica, 320 Yue-Yang Road, Shanghai 200031, China

\begin{abstract}
The psr region of Rhizobium leguminosarum biovar phaseoli had originally been recognized on the basis of its ability to repress the transcription of the psi genes, one of which, psiA, inhibits exopolysaccharide synthesis when cloned in multi-copy plasmids. Both psr and psi are located on the symbiotic plasmid pRP2J. The psrA gene was localized and sequenced. The deduced amino acid sequence of PsrA was shown to have similarity to the DNA-binding region of a family of other transcriptional regulators, consistent with its known effects on the expression of psi. The transcription of psrA itself appears to be constitutive in free-living Rhizobium, but is regulated by another gene on the Sym plasmid pRP2J.
\end{abstract}

Keywords: Rhizobium, exopolysaccharide, $p s i, p s r$, transcriptional regulation

\section{INTRODUCTION}

Strains of Rbizobium synthesize large amounts of extracellular, high molecular mass, acidic exopolysaccharide (EPS). Genetic studies have shown that, at least in certain strains or species of Rhizobium, this polymer is important for the induction of normal, nitrogen-fixing nodules on leguminous plants (reviewed in Leigh \& Coplin, 1992; Gray \& Rolfe, 1990; Reuber et al., 1991b). Thus, in R. meliloti, (exo) mutants, defective in EPS production induce nodules on alfalfa which are devoid of bacteria and which fail to fix $\mathrm{N}_{2}$ (e.g. Leigh et al., 1985, 1987) and those in $\mathrm{R}$. leguminosarum biovar (bv.) viciae fail to induce nodules at all on peas (Borthakur et al., 1986). Interestingly, though, exo mutants of Rhizobium strains which infect plants with determinant nodules, as, for example, those on Phaseolus beans by $R$. leguminosarum bv. phaseoli, appear to be unaffected in symbiotic nitrogen fixation [e.g. Borthakur et al. (1986) and see, also, Hotter \& Scott (1991)].

In R. meliloti, where the most detailed genetic studies in Rhizobium on exo genes have been conducted, most of them are clustered (Long et al., 1988) on a large indigenous

\section{Abbreviations: EPS, exopolysaccharide.}

The GenBank accession number for the sequence reported in this paper is L26581. plasmid, different from the so-called pSym which contains many of the nod, nif and fix genes (Finan et al., 1986; Hynes et al., 1986).

In a strain of R. leguminosarum bv. phaseoli, a gene termed psi was identified on pRP2JI, the pSym of this biovar, which has significant effects on the production of EPS and on nodulation and nitrogen fixation (Borthakur et al., 1985). The $p$ si region is close to several nod and nif genes on the symbiotic plasmid pRP2JI (Lamb et al., 1985; Borthakur et al., 1985; Davis \& Johnston, 1990a, b; Hawkins \& Johnston, 1988). It was initially identified because, when it was cloned in a wide-host-range, multicopy plasmid vector such as pLAFR 1 or pKT230, it inhibited production of EPS by R. leguminosarum; hence its name, polysaccharide inhibition. One gene, psi $A$, was sufficient for this phenotype. The product of $p s i A$ is a small $(10 \mathrm{kDa})$ protein that is probably located in the inner membrane of Rhizobium (Borthakur \& Johnston, 1987; Latchford et al., 1991). psi $A$ is part of a larger transcriptional unit which contains at least one upstream gene whose product is also associated with the bacterial membrane(s) or periplasm (Latchford et al., 1991). Mutations in psiA do not appear to affect EPS synthesis but such mutants are defective in symbiotic nitrogen fixation on beans, inducing non-fixing nodules that are devoid of bacteria (Borthakur et al., 1985).

A gene, termed exoX, with similar properties to $p s i A$ was identified in R. meliloti (Reed et al., 1991a) and Rbizobium 
strain NGR234 (Gray et al., 1990). When present in multicopy, exoX also inhibits EPS synthesis; further, the hydropathy profiles of ExoX and PsiA are very similar (extremely hydrophobic $\mathrm{N}$ half and hydrophilic $\mathrm{C}$ half) although actual sequence similarities of the two proteins were limited to a small tract of 14 amino acids in the middle of the proteins. Note that in contrast to $p s i A$, the exoX gene of $R$. meliloti is not on the Sym plasmid but is among the large cluster of other exo genes. It has been suggested that PsiA/ExoX functions as a posttranslational inhibitor of PssA/ExpY, a structural protein involved in EPS synthesis (Gray et al., 1990; Borthakur et al., 1988; Reuber et al., 1991b).

It was proposed that the function of $p s i A(\operatorname{exo} X)$ was to inhibit EPS synthesis by R. leguminosarum during normal nodule development. Bacteroids within nodules make little or no EPS (Tulley \& Terry, 1985) and it was suggested (Borthakur et al., 1985) that, normally, psi was expressed only during infection of legumes and not in the free-living state. Direct evidence to support this was subsequently obtained using $p s i-$ uid $A$ fusions (Latchford et al., 1991). Also, consistent with this was the observation that psi mutants of $R$. leguminosarum bv. phaseoli induced non-fixing nodules that were devoid of bacteria (Borthakur et al., 1985) indicating that if EPS synthesis were not switched off, an aberrant infection would ensue.

It was further proposed that by cloning $p s i$ in a multi-copy vector, its expression became 'deregulated' and that its influence on EPS production would be seen in free-living bacteria. (Borthakur et al., 1985). It is certainly clear that transcription of $p s i$ is under regulatory control. A region of DNA on pRP2JI approximately $13 \mathrm{~kb}$ from psi was identified which had the following two properties. When this region was itself cloned in one plasmid (pLAFR1) and introduced into a non-mucoid strain containing multicopy $p s i$ on a compatible plasmid (pKT230), the transconjugants regained their ability to make EPS (Borthakur \& Johnston, 1987). The gene(s) responsible for this was termed $p s r$ (polysaccharide restoration). Further, using $p s i-l a c Z$ and $p s i-p b o A$ fusions, it was shown that this effect was because $p s r$ repressed the transcription of $p s i$; thus by having 'extra' copies of $p s r$, this overcame the inhibition of EPS synthesis caused by multi-copy $p s i$ (Borthakur \& Johnston, 1987; Latchford et al., 1991).

A strain of $R$. leguminosarum bv. phaseoli with a psr:: $\operatorname{Tn} 5$ mutation induced normal nitrogen-fixing nodules on Phaseolus beans. Strains with multi-copy $p s r$, though, induced non-fixing 'empty' nodules which could be interpreted as being due to the lack of expression of $p s i$ in the bacteria during the infection; i.e. strains with multicopy psr would mimic those with psi mutations (Borthakur \& Johnston, 1987).

In this paper, we describe the detailed location of $p s r$, show that its product has a striking similarity to other transcriptional regulatory proteins, and that the expression of psr is, in turn, regulated by another gene on the Sym plasmid.

\section{METHODS}

Bacterial strains, plasmids and growth conditions. These are shown in Table 1. E. coli strains were routinely cultured on Luria Broth (LB), Rbizobium on TY solid or liquid media (Beringer, 1974). For Rbizobium, antibiotics were added as appropriate as follows in $\mu \mathrm{g} \mathrm{ml}^{-1}$ : kanamycin (20), tetracycline (5), streptomycin (200). 5-Bromo-4-chloro-3 indolyl galactoside (X-Gal) was incorporated at $40 \mu \mathrm{g} \mathrm{ml}^{-1}$. $\beta$-Galactosidase was assayed according to Rossen et al. (1985). EPS phenotypes were scored on TY solid medium.

Genetic manipulations. Plasmids were transferred by conjugation from $E$. coli to Rbizobium in tri-parental matings as described by Buchanan-Wollaston et al. (1980) using the plasmid pRK2013 as a helper to mobilize the pMP220-based recombinant plasmids.

DNA manipulations. Restriction digestions, ligations and transformations were done essentially as described by Maniatis et al. (1982). Subcloning various fragments (see Fig. 1) of the psr region into pMP220 usually involved some 'shuttling' in which relevant fragments were obtained from $\mathrm{pIJ1426}$, cloned into appropriate sites of pUC18 before recloning into the polylinker of pMP220. Details of plasmid construction are as follows.

pBIO132/133. The region of DNA containing $p s r A$ was cloned as a 1240 bp $S p b \mathrm{I} / E c o R V$ DNA fragment into pUC19 SpbI/ SmaI. The resulting plasmid, pBIO138, was then digested with HindIII/SacI to release the DNA fragment and subsequently filled-in with T4 DNA polymerase. This DNA fragment was cloned in both orientations into the $S m a \mathrm{I}$ restriction site of Bluescript $\mathrm{SK}-$ to give the plasmids pMLM152 and pMLM153, which were digested with EcoRI/XbaI to release the psr $A$-containing DNA fragments which were finally cloned into pMP220 to give the resulting plasmids pBIO132/133.

pBIO137. pBIO138 was digested with $B g / \mathrm{II}$ and filled-in using T4 DNA polymerase and checked for loss of the unique $B g l \mathrm{II}$ restriction site in the region of the $\operatorname{psr} A$ gene by restriction endonuclease digestion and sequencing. This plasmid, pMLM42, was further digested with EcoRI/HindIII to release the $p s r A$-containing DNA fragment which was cloned into pLAFR3 to generate pBIO137.

pBIO134. pMLM153 (see above) was digested with DraI/EcoRI releasing the $\operatorname{ps} A$ DNA fragment which was cloned into Bluescript SK - SmaI/EcoRI to give pMLM169; this was digested with EcoRI/XbaI and the fragment was cloned into pMP220 to generate pBIO134.

pBIO135. pMLM153 was digested with $B g l \mathrm{II} /$ EcoRI to release a DNA fragment cloned into pMP220 BglII/EcoRI to generate the plasmid pBIO135.

pBIO136. pBIO138 was digested with EcoRI/Pst I and the psr A fragment was cloned into pMP220 to generate the plasmid pBIO136.

The psr $A-l a c Z$ translational fusion plasmid pBIO142 was made as follows. The 1240 bp $S p h \mathrm{I} / E c o \mathrm{RV}$ psr $A$ fragment was cloned into the HincII site of pUC18. The resulting plasmid was digested with EcoRI/PstI (the PstI site is within psr $A$ ) and the truncated $\operatorname{psr} A$ was ligated into Bluescript SK before being taken out as a BamHI fragment and ligated to BamHI-cut pIJ1363. The authenticity of the fusion was checked by sequencing: it was confirmed that $p s r A$ and $\operatorname{lac} Z$ were fused inframe and in the correct orientation. To form the 'promotertrap plasmid' $\mathrm{pBIO} 143$, a fragment containing the 5 ' end of psr $A$ plus a region immediately upstream of it was made by PCR 
Table 1. Strains and plasmids used in this study

\begin{tabular}{|c|c|c|}
\hline Strain/plasmid & Relevant features & Source \\
\hline \multicolumn{3}{|l|}{ Escherichia coli } \\
\hline 803 & Used for routine transformations & Wood (1966) \\
\hline JM101 & $\begin{array}{l}\text { Used as a host for pUC18- and pUC19-derived } \\
\text { plasmids }\end{array}$ & Maniatis et al. (1982) \\
\hline \multicolumn{3}{|c|}{ Rhizobium leguminosarum } \\
\hline 8401 & Str ${ }^{r}$, cured of its Sym plasmid & Lamb et al. (1982) \\
\hline KH1014 & $8401 \mathrm{pRL1} J I$, lac: $: \operatorname{Tn} 5$ & Rossen et al. (1985) \\
\hline 4292 & Wild-type R. leguminosarum bv. phaseoli, rif & Lamb et al. (1982) \\
\hline JW167 & $\begin{array}{l}\text { Nod }^{-} \text {mutant of } R \text {. leguminosarum bv. phaseoli } \\
\text { contains } 50-60 \mathrm{~kb} \text { deletion in pRP } 2 \mathrm{JI}\end{array}$ & Lamb et al. (1982) \\
\hline \multicolumn{3}{|c|}{ 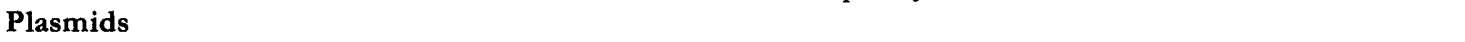 } \\
\hline pRP2JI & $\begin{array}{l}\text { Sym plasmid of R. leguminosarum bv. phaseoli } \\
\text { strain } 8002\end{array}$ & Lamb et al. (1982) \\
\hline pKT230 & Q-group cloning vector; $\operatorname{Kan}^{r} \operatorname{Str}^{r}$ & Bagdasarian et al. (1981) \\
\hline plJ1393 & Contains psi in pKT230 & Borthakur et al. (1985) \\
\hline pIJ1363 & P1-group lac $Z$ translational fusion vector & Rossen et al. (1985) \\
\hline pMP220 & P1-group cloning vector & Spaink et al. (1987) \\
\hline pML122 & Q-group cloning vector & Labes et al. (1990) \\
\hline pIJ1426 & $p s r$ region cloned in $\mathrm{pKT} 230$ & $\begin{array}{l}\text { Borthakur \& Johnston } \\
\text { (1987) }\end{array}$ \\
\hline pBIO142 & lac $Z-p s r A$ fusion in $\mathrm{pIJ} 1363$ & This work \\
\hline pBIO143 & psr $A$ promoter in pML122 & This work \\
\hline \multicolumn{3}{|l|}{ pBIO1327 } \\
\hline pBIO133 & Derivatives of pMP 220 or pLAFR 3 containing & This work \\
\hline pBIO134 & various fragments of the $p s r$ region & \\
\hline pBIO135 & See Fig. 1 & \\
\hline pBIO136 & & \\
\hline \multicolumn{3}{|l|}{ pBIO137 } \\
\hline pBIO138 & $\begin{array}{l}\text { SphI-EcoRI fragment containing } p s r A \text {, cloned } \\
\text { in pUC19 }\end{array}$ & This work \\
\hline
\end{tabular}

amplification using the oligonucleotide primers J82 and J84 shown in Fig. 2. This fragment was cloned first into HincII-cut pUC18 and thence into the wide-host-range plasmid pML122 (HindIII/BamHI) to form pBIO143.

The sequence of the $833 \mathrm{bp} D r a \mathrm{I}-S p h \mathrm{I}$ psr $A$-containing fragment was determined for both strands by sequencing out in both directions from the DraI, BglII, ClaI, PstI and SpbI sites shown in Fig. 1, relevant fragments having been cloned in pUC18 or pUC19. Clones that spanned these restriction sites were also obtained (G. F. Hong, unpublished) to complete the sequence of the psr region. Sequencing was done using the Sanger, dideoxy method using a Pharmacia ALF automated sequencer according to the manufacturer's instructions.

\section{RESULTS AND DISCUSSION}

\section{Location of psrA}

Borthakur \& Johnston (1987) isolated two pLAFR1based cosmids, pIJ1399 and pIJ1400, both of which overcame the EPS ${ }^{-}$phenotype of a strain containing multi-copy psi. By subcloning fragments of pIJ1399 into pKT230, the psr gene(s) was located within a $4 \mathrm{~kb}$ EcoRI-SacI fragment. This fragment, cloned in pKT230 to form pIJ1426 suppressed the effect of multi-copy $p s i$ on EPS synthesis and was also shown to be sufficient to repress transcription of $p s i-l a c Z$ and $p s i-p h o A$ fusions (Borthakur \& Johnston, 1987; Latchford et al., 1991). Further, a psr:: $\operatorname{Tn} 5$ mutation was located within this same region of $\mathrm{pIJ} 1399$.

A more detailed restriction map of the $4 \mathrm{~kb} p s r$ DNA was compiled, and individual fragments were cloned in the wide-host-range vector pMP220 (Fig. 1). The various resulting plasmids were each mobilized into $R$. leguminosarum strain 8401 containing pIJ1393 (psi cloned in $\mathrm{pK} T 230)$. The transconjugants were scored for their mucoid colony morphology and by such means psr was localized to a region of just under $1 \mathrm{~kb}$ (see Fig. 1) defined by the region between the DraI and $S p h \mathrm{I}$ sites shown in Fig. 1. Thus, fragments lacking DNA to the left of the BglII site ( $\mathrm{pBIO135)}$ or to the right ( $\mathrm{pBIO136)}$ of the Pst $\mathrm{I}$ site (as shown in Fig. 1) did not suppress the Psi phenotype.

The vector pMP220 does not have a promoter at its polylinker cloning site. Thus any plasmid expressing Psr activity must not only contain the $p s r$ gene, but upstream 


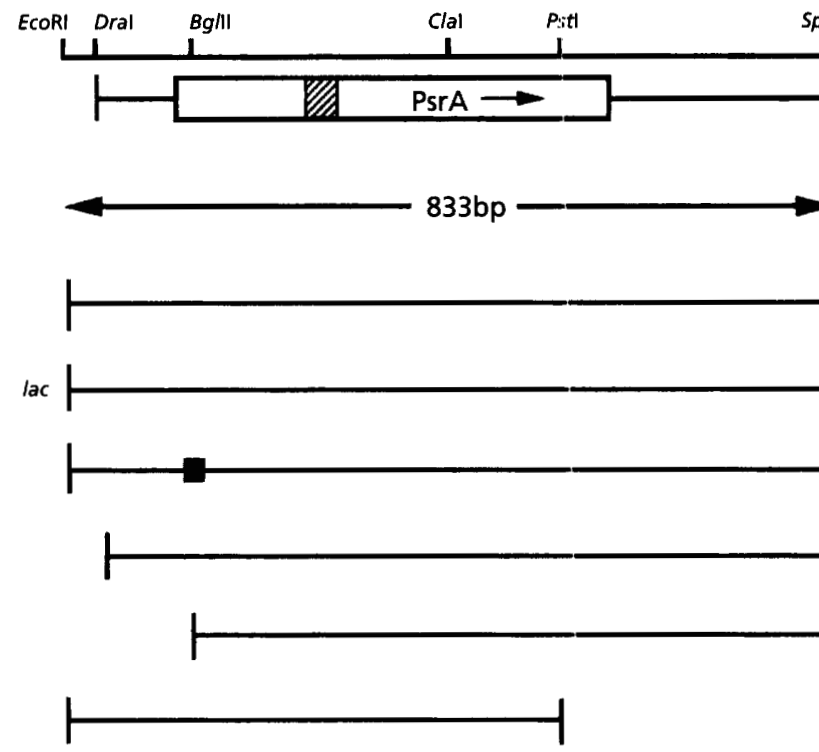

$\begin{array}{ll}\text { Plasmid } & \text { Psr activity } \\ \text { pBl0132 } & + \\ \text { pBI0133 } & + \\ \text { pBI0137 } & \text { - } \\ \text { pBI0134 } & \text { + } \\ \text { pBI0135 } & - \\ \text { pBI0136 } & -\end{array}$

\begin{abstract}
Fig. 1. Map of the psr region. Relevant restriction sites in the psr region are shown. The numbering refers to positions in the sequence presented in Fig. 2. The dimensions of the fragments cloned in pMP220 and the Psr phenotype of the resulting plasmids are shown. In pBIO132 and pBIO133 the location of the vector lacZ gene relative to the cloned fragment is presented. The open boxed region defines the extent of the psrA open reading frame and the hatched shaded region defines the position of the DNA-binding domain within the psrA gene. In pBIO137 the ( $\square$ ) refers to the modified Bg/ll site.
\end{abstract}

sequences responsible for its transcription. Immediately downstream of the polylinker is the lac $Z$ gene of $E$. coli. The EcoRI-SphI fragment had been cloned in both orientations to form $\mathrm{pBIO} 132$ and $\mathrm{pBIO} 133$ each of which was transferred to R. leguminosarum strain KH1014, which lacks the constitutive, $R$. leguminosarum $\beta$ galactosidase. The transconjugants were streaked on medium containing X-Gal. The strain containing pBIO132 formed pale-blue colonies whereas those with pBIO133 were white. This indicated that transcription of the cloned DNA was from left to right as drawn in Fig. 1 (and see below).

\section{Sequence determination of psrA}

The 833 bp DraI-SpbI fragment containing psr was sequenced (Fig. 2). One ORF in the appropriate orientation (left to right as drawn in Fig. 1) was identified which spanned both the PstI and the BglII sites that had been shown to be required for $p s r$ function (see above). It is proposed that the ORF corresponds to a gene termed $\operatorname{psr} A$ which starts at a GTG at position 95 , just $10 \mathrm{bp}$ upstream of the BglII site. To confirm that the DNA at this $B g l I I$ site was needed for $p s r$ function, a plasmid (pBIO138) containing the $S p h \mathrm{I}-E c o \mathrm{RI}$ fragment, cloned in pUC19, was cleaved with $B g l \mathrm{II}$, the ends were filled in and blunt-end ligated (the $B g l$ II site in $\operatorname{ps} A$ is the only one present in pBIO138). The modified SpbI-EcoRI fragment was then ligated to pMP220 and the resulting plasmid, pBIO137, was tested for Psr function as described above. As indicated in Fig. 1, pBIO137 no longer suppressed the EPS ${ }^{-}$phenotype caused by multi-copy $p s i$, confirming the requirement for the sequence immediately spanning the $B g l$ II site.

Note that the PstI site lies only 48 nt upstream of the $3^{\prime}$ end of $p s r A$. The failure of pBIO136 (Fig. 1) to suppress the Psi phenotype thus shows that the C-terminal 16 amino acids of PsrA are essential for its function.

\section{PsrA resembles other transcriptional regulators}

The deduced polypeptide product of $p s r A$ has molecular mass of $18092 \mathrm{Da}$ and its sequence was compared with those in databases. As shown in Fig. 3, it is clear that PsrA is a member of a family of transcriptional regulators, consistent with its known ability to repress $p$ si expression. Largely, this similarity was confined to the helix-turnhelix DNA-binding domains of these regulatory proteins, the regions in which they themselves show greatest similarity to each other. There were, though, other intermittent matches elsewhere in the proteins, the most pronounced being that between PsrA and Gene C, a repressor in bacteriophage $\mathrm{P} 2$.

The group of regulatory proteins to which PsrA is related comprises those that are repressors (e.g. cI), those that are activators [e.g. UhpR; see Friedrich \& Kadner (1987)] and those that can have either function at different promoters (e.g. Fnr). To date, the only regulatory property attributed to PsrA is its ability to repress the psi operon and further work will be required to establish if it can act positively or negatively on other Rbizobium promoters. 


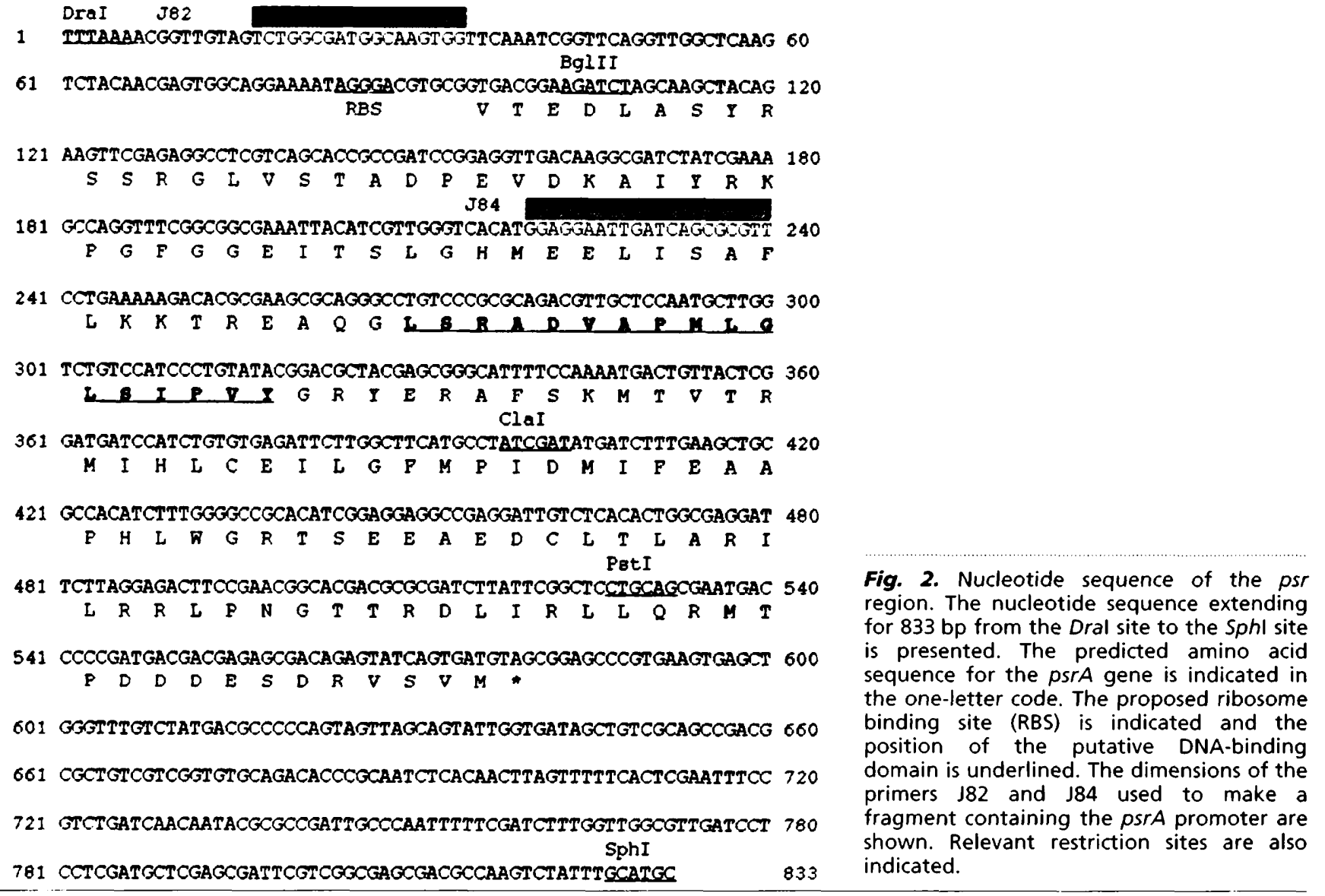

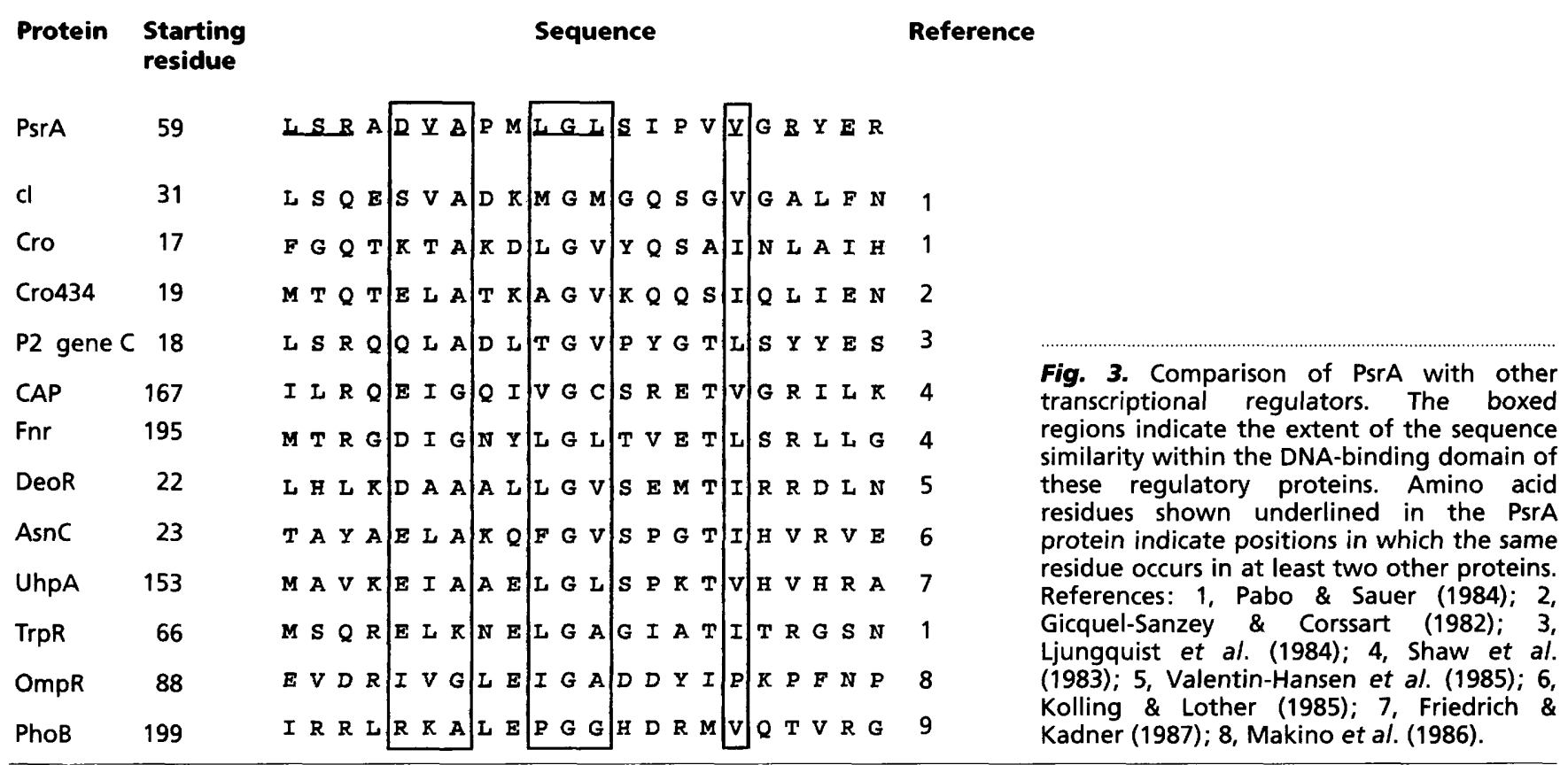

To date, no gene analogous or homologous to psr $A$ has been found within the rhizobia. It has no similarity in sequence to exoR (Doherty et al., 1988; Reed et al., 1991a), a regulatory gene in $R$. meliloti which can repress transcription of several exo 'structural' genes in that species. 
psrA is regulated by another gene on Sym plasmid PRP2J

Sequence analysis and expression of $l a c Z$ from the cloned psr $A$ region in pMP220 (see above) strongly indicated that $\operatorname{psr} A$ was transcribed from left to right as shown in Fig. 1 and that the $p s r A$ promoter was located between the $D r a \mathrm{I}$ site and the start of $\operatorname{psr} A$. To confirm this, the psr A-lac $Z$ translational fusion plasmid pBIO142 was made (see Methods).

pBIO142 was mobilized into R. leguminosarum bv. phaseoli wild-type strain 4292 and also into its derivative 8401 in which the Sym plasmid pRP2JI is missing. The transconjugants were plated on media supplemented with $\mathrm{X}$ Gal. The derivative of strain 4292 stained more brightly blue than that of strain 8401 indicating that pRP2JI contained a gene or genes that activated transcription of $p s r A$. In quantitative assays it was found that in the wildtype background the fusion expressed $\beta$-galactosidase at a level equivalent to 250 units. In contrast, in the cured strain 8401 , there was only 31 units of $\beta$-galactosidase, little above background (12 units).

This regulatory gene was shown to be in the vicinity of the symbiotic (nod/nif) region of pRP2JI; when pBIO142 was mobilized into strain JW167, which has a large $(50-60 \mathrm{~kb})$ deletion that removes nod and nif genes, the transconjugants were pale-blue on X-Gal.

We obtained evidence that the regulatory gene in $\mathrm{pRP} 2 \mathrm{JI}$ specifies a product that binds to sequences upstream of psr $A$ in free-living $R$. leguminosarum bv. phaseoli. A plasmid, pBIO143 containing the region upstream of $\operatorname{psr} A$ (see Fig. 1 and Methods) was introduced into the wild-type R. leguminosarum bv. phaseoli strain 4292 containing the psrA-lacZ fusion plasmid pBIO142; the presence of $\mathrm{pBIO} 143$ reduced the level of $\beta$-galactosidase from 250 to 60 Miller units. Since pBIO143 contains the psr $A$ promoter cloned in the relatively high copy number plasmid pKT230, we interpret this reduction of expression of the psr $A-l a c Z$ fusion as being due to the binding of the activator protein to the promoter in pBIO143, thus reducing the level available for inducing transcription of the $p s r A-l a c Z$ fusion.

The $p s r A-l a c Z$ fusion plasmid pBIO142 was also introduced into the $R$. leguminosarum bv. viciae strain 8401 pRL1JI. The levels of $\beta$-galactosidase were the same as those obtained when pBIO142 was present in strain 8401, which lacks any Sym plasmid. Thus it would appear that there is not a corresponding gene on the Sym plasmid of biovar viciae which can activate transcription of $\operatorname{psr} A$.

It is not clear why the regulation of $p s i$ in $R$. leguminosarum bv. phaseoli appears to be so different from that of its analogue, exoX, in $R$. meliloti. There are, for example, no striking similarities in the sequences upstream of exoX and the cis-acting regulatory region of $p s i$.

It is clear that $\operatorname{psr} A$, whose product has similarity to a family of transcriptional regulators, is sufficient to repress transcription of the psi operon. Since, under normal circumstances, $p s i$ is expressed in the bacteroids but not in the free-living bacteria, it might have seemed reasonable to suppose that the role of $p s r A$ is to keep transcription of $p s i$ quiescent in the latter form but that, in some way, in the bacteroids $p s i$ is no longer subject to $p s r A$-mediated repression. However, it is also apparent that the regulation and the effects of expression of psi must be more complex than being simply subject to repression by $p s r A$. We can deduce this from the fact that $p s r$ mutants are phenotypically normal for EPS synthesis in in vitro Rbizobium. Thus, other factors must be required for the high level expression of psi in Pbaesolus nodules. These may be mediated by factors which control expression of $p s r A$ itself. It is clear from results obtained here that the Sym plasmid pRP2JI contains a gene or genes that, in turn, regulate transcription of $\operatorname{psr} A$; it will be of interest to identify the nature of this regulatory gene.

\section{ACKNOWLEDGEMENTS}

This work was supported by the Agricultural and Food Research Council and from a grant to G.F.H. from the Rockefeller Foundation. We are grateful to Alan Cavill for excellent technical assistance and to Fiona Hawkins and John Latchford for preliminary results.

\section{REFERENCES}

Bagdasarian, M., Lurz, R., Ruckert, B., Franklin, F. C. H., Bagdasarian, M. M., Frey, J. \& Timmis, K. T. (1981). Specific-purpose plasmid cloning vectors. II. Broad host range, high copy RSF1010derived vectors and a host-vector system for gene cloning in Pseudomonas. Gene 16, 237-247.

Beringer, J. E. (1974). R factor transfer in Rbizobium leguminosarum. $J$ Gen Microbiol 83, 188-198.

Borthakur, D. \& Johnston, A. W. B. (1987). Sequence of $p s i$, a gene on the symbiotic plasmid of Rhizobium phaseoli which inhibits exopolysaccharide synthesis and nodulation and demonstration that its transcription is inhibited by $p s r$, another gene on the symbiotic plasmid. Mol \& Gen Genet 207, 149-154.

Borthakur, D., Barber, C. E., Lamb, J. W., Daniels, M. J., Downie, J. A. \& Johnston, A. W. B. (1986). A mutation that blocks exopolysaccharide synthesis prevents nodulation of peas by $\mathrm{Rhi}$ zobium leguminosarum but not of beans by $R$. phaseoli and is corrected by cloned DNA from Rhizobium or the phytopathogen Xanthomonas. Mol \& Gen Genet 203, 320-323.

Borthakur, D., Barker, R. F., Latchford, J. W., Rossen, L. \& Johnston, A. W. B. (1988). Analysis of pss genes of Rbizobium leguminosarum required for exopolysaccharide synthesis and nodulation of peas: their primary structure and their interaction with $p s i$ and other nodulation genes. Mol \& Gen Genet 213, 155-162.

Borthakur, D., Downie, J. A., Johnston, A. W. B. \& Lamb, J. W. (1985). psi, a plasmid-linked Rbizobium phaseoli gene that inhibits exopolysaccharide production and which is required for symbiotic nitrogen fixation. Mol \& Gen Genet 200, 278-282.

Buchanan-Wollaston, A. V., Beringer, J. E., Brewin, N. J., Hirsch, P. R. \& Johnston, A. W. B. (1980). Isolation of symbiotically defective mutants in Rbizobium leguminosarum by insertion of the transposon $\operatorname{Tn} 5$ into a transmissible plasmid. Mol \& Gen Genet 178, 185-190.

Davis, E. O. \& Johnston, A. W. B. (1990a). Analysis of three nodD genes in Rhizobium leguminosarum biovar phaseoli; nodD1 is preceded by nolE, a gene whose product is secreted from the cytoplasm. Mol Microbiol 4, 921-932. 
Davis, E. O. \& Johnston, A. W. B. (1990b). Regulatory functions of the three nodD genes of Rbizobium leguminosarum biovar phaseoli. Mol Microbiol 4, 933-941.

Doherty, D., Leigh, J. A., Glazebrook, J. \& Walker, G. C. (1988). Rhizobium meliloti mutants that over produce the $\mathrm{R}$. meliloti acidic calcofluor-binding exopolysaccharide. J Bacteriol 170, 4249-56.

Finan, T. M., Kunkel, B., De Vos, G. F. \& Signer, E. R. (1986). Second symbiotic megaplasmid in Rbizobium meliloti carrying exopolysaccharide and thiamine synthesis genes. $J$ Bacteriol 167, $66-72$

Friedrich, M. J. \& Kadner, R. J. (1987). Nucleotide sequence of the ubp region of Eschericbia coli. J Bacteriol 169, 3556-3563.

Gicquel-Sanzey, B. \& Crossart, P. (1982). Homologies between different prokaryotic DNA-binding regulatory proteins and between their sites of action. EMBO J 1, 591-595.

Gray, J. X. \& Rolfe, B. G. (1990). Exopolysaccharide production in Rhizobium and its role in invasion. Mol Microbiol 4, 1425-31.

Gray, J. X., Djordjevic, M. A. \& Rolfe, B. G. (1990). Two genes that regulate exopolysaccharide production in Rhizobium sp. strain NGR234: DNA sequences and resultant phenotypes. I Bacteriol 172, 193-203.

Hawkins, F. K. L. \& Johnston, A. W. B. (1988). Transcription of a Rhizobium leguminosarum biovar phaseoli gene needed for melanin synthesis is activated by nif $A$ of Rhizobium and Klebsiella pneumoniae. Mol Microbiol 2, 331-337.

Hotter, G. S. \& Scott, D. B. (1991). Exopolysaccharide mutants of Rhizobium loti are fully effective on a determinate nodulating host but are ineffective on an indeterminate nodulating host. $J$ Bacteriol 173, 851-59.

Hynes, M. F., Simon, R., Muller, P., Niehaus, K., Labes, M. \& Puhler, A. (1986). The two megaplasmids of Rbizobium meliloti are involved in the effective nodulation of alfalfa. Mol \& Gen Genet 202, 356-62.

Kolling, R. \& Lother, H. (1985). AsnC: an autogenously regulated activator of asparaginase synthetase A transcription in Escherichia coli. J Bacteriol 164, 310-315.

Labes, M., Puhler, A. \& Simon, R. (1990). A new family of RSF1010-derived expression and lac fusion broad host-range vectors for Gram negative bacteria. Gene 89, 37-46.

Lamb, J. W., Hombrecher, G. \& Johnston, A. W. B. (1982). Plasmiddetermined nodulation and nitrogen-fixation abilities in Rbizobium phaseoli. Mol \& Gen Genet 186, 449-452.

Lamb, J. W., Downie, J. A. \& Johnston, A. W. B. (1985). Cloning of the nodulation (nod) genes of Rbizobium phaseoli and their homology to R. leguminosarum nod DNA. Gene 34, 235-241.

Latchford, J. W., Borthakur, D. \& Johnston, A. W. B. (1991). The products of Rhizobium genes, psi and pss, which affect exopolysaccharide production, are associated with the bacterial cell surface. Mol Microbiol 5, 2107-2114.

Leigh, J. A. \& Coplin, D. L. (1992). Exopolysaccharides in plantbacterial interactions. Annu Rev Microbiol 46, 307-46.

Leigh, J. A., Reed, J. W., Hanks, J. F., Hirsch, A. M. \& Walker, G. C. (1987). Rbizobium meliloti mutants that fail to succinylate their calcofluor-binding exopolysaccharide are defective in nodule invasion. Cell 51, 579-87.

Leigh, J. A., Signer, E. R. \& Walker, G. C. (1985).
Exopolysaccharide-deficient mutants of Rbizobium meliloti that form ineffective nodules. Proc Natl Acad Sci US A 82, 6231-35.

Ljungquist, E., Kockum, K. \& Bertani, E. L. (1984). DNA sequences of the repressor gene and operator region of bacteriophage P2. Proc Natl Acad Sci US A 81, 3988-3992.

Long, S., Reed, J. W., Himawan, J. \& Walker, G. C. (1988). Genetic analysis of a cluster of genes required for synthesis of the calcofluorbinding exopolysaccharide of Rbizobium meliloti. J Bacteriol 170, 4239-48.

Makino, K., Shinagawa, H., Amemura, M. \& Nakata, A. (1986). Nucleotide sequence of the $p h o B$ gene, the positive regulatory gene for the phosphate regulon of Escherichia coli K-12. J Mol Biol 190, 37-44.

Maniatis, T., Fritsch, E. F., Sambrook, J. (1982). Molecular Cloning: A Laboratory Manual. Cold Spring Harbor, NY: Cold Spring Harbor Laboratory.

Pabo, C. O. \& Sauer, R. T. (1984). Protein-DNA recognition. Annu Rev Biocbem 53, 293-321.

Reed, J. W., Capage, M. \& Walker, G. C. (1991a). Rhizobium meliloti exoG and exoJ mutations affect the ExoX-ExoY system for modulation of exopolysaccharide production. $J$ Bacteriol 173, 3776-88.

Reed, J. W., Glazebrook, J. \& Walker, G. C. (1991b). The exoR gene of Rbizobium meliloti affects RNA levels of other exo genes but lacks homology to known transcriptional regulators. J Bacteriol 173, 3789-94.

Reuber, T. L., Long, S. \& Walker, G. C. (1991a). Regulation of Rbizobium meliloti exo genes in free-living cells and in planta examined by using Tnpho $A$ fusions. $J$ Bacteriol 173, 426-34.

Reuber, T. L., Reed, J., Glazebrook, J., Glucksman, M. A., Ahmann, D. \& Waller, G. C. (1991b). Rhizobium meliloti exopolysaccharides: genetic analyses and symbiotic importance. Biocbem Soc Trans 19, 636-41.

Rossen, L., Shearman, C. A., Johnston, A. W. B. \& Downie, J. A. (1985). The nodD gene of Rhizobium leguminosarum is autoregulatory and in the presence of plant exudate induces the nod $A B C$ genes. EMBO J 4, 3369-3373.

Shaw, D. J., Rice, D. W. \& Guest, J. R. (1983). Homology between $\mathrm{CAP}$ and Fnr, a regulator of anaerobic respiration in Escherichia coli. $J$ Bacteriol 166, 241-247.

Spaink, H. P., Okker, J. H., Wijffelman, C. A., Pees, E. \& Lugtenberg, B. J. J. (1987). Promoters in the nodulation region of the Rbizobium leguminosarum Sym plasmid pRL1 JI. Plant Mol Biol 9 , 27-39.

Tulley, R. E. \& Terry, M. E. (1985). Decreased exopolysaccharide synthesis by anaerobic and symbiotic cells of Bradyrbizobium japonicum. Plant Pbysiol 79, 445-450.

Valentin-Hansen, P., Hojrup, P. \& Short, S. (1985). The primary structure of the DeoR repressor from Escherichia coli K-12. Nucleic Acids Res 13, 5926-5936.

Wood, W. B. (1966). Host specificity of DNA produced by E. coli bacterial mutations affecting the restriction and modification of DNA. J Mol Biol 16, 118-133.

Received 7 June 1993; revised 18 October 1993; accepted 11 November 1993. 